\author{
Szegedi Tudományegyetem, Fogorvostudományi Kar, Fogpótlástani Tanszék, Szeged* \\ Dentha Fogászati Bt, Szeged** \\ Szegedi Tudományegyetem, Fogorvostudományi Kar, Orális Biológiai és Kísérletes Fogászati Tanszék, Szeged*** \\ Pécsi Tudományegyetem Fogorvostudományi Szak, Fogpótlástani Tanszék, Pécs ${ }^{\star \star * *}$
}

\title{
Részleges kivehető fémlemezes múfogsorok tervezése a hazai gyakorlatban II.
}

\author{
DR. RADNAI MÁRTA*, DR. BARÁTH ZOLTÁN* ${ }^{*}$ DR. ALBERT BALÁZS**, \\ TARJÁNYI TAMÁS ${ }^{* * *}$, DR. MARADA GYULA****
}

\begin{abstract}
Szakmai irányelvek, jogi, etikai útmutatók és szabályok vonatkoznak a fogorvosok feladataira és kötelességeire a betegellátással kapcsolatban, ezen belül az öntött kapocs elhorgonyzású részleges kivehető fémlemezes múfogsorok készítésére is. Vizsgálatunk célja volt annak felmérése, hogy a mindennapi gyakorlat szerint milyen mértékben követik ezen előírásokat a fogorvosok. Kérdőíves módszerrel gyújtöttük az adatokat, és 88 fogorvos válaszait dolgoztuk fel. Eredményeink szerint a fogorvosoknak körülbelül fele $(54,5 \%)$ küld pontos tervet fémlemez készítéséhez a laborba, a kapocstartó fogakat $88,5 \%$ jelöli meg, a kapcsok típusát $65,9 \%$ választja ki, a nagy összekötőkre nézve pedig 55,8\%-uk ad utasítást. Az információátadás kisebbrészt rajzban (7 fő, 8,1\%), nagyobbrészt szövegesen ( 29 fő, 33,7\%) történik meg, és a legtöbben (50 fö, 58,2\%) rajzos és szöveges utasítást küldenek. A fogorvosok nagyrészt készek a felelősséget vállalni hiba esetén, és fontosnak tartják a közös tervezést. Ahhoz, hogy az elöírásoknak megfelelően a fogorvosok mindig, de legalábbis gyakrabban tervezzék meg a kivehető részleges fémlemezes fogpótlásokat a beteggel kapcsolatos információk birtokában, szükséges lenne az egyetemi képzésben és a továbbképzéseken az ilyen típusú pótlások készítéséhez szükséges elméleti és gyakorlati ismeretek bővítése.
\end{abstract}

Kulcsszavak: felelősség, fogorvos, fogtechnikus, öntött kapocs elhorgonyzású részleges kivehető fémlemezes múfogsor, tervezés

\section{Bevezetés}

$A$ részleges fémlemezes müfogsor gyógyászati segédeszköz, melyre a fogorvosnak mint „gyártónak” felelősséget kell vállalni [14]. Jogi értelemben a beteg a fogorvosi szolgáltatás szakszerű és gondos elvégzését várja, és a szolgáltatás teljesítésével a fogorvos ezt vállalja. A fogorvos felelőssége szakmai, etikai, polgári jogi és büntetőjogi értelemben is szabályozott; többek között az 1997. évi CLIV. törvény az egészségügyről [5], a Magyar Orvosi Kamara Etikai kódexe [1], a Polgári törvénykönyv [9] tartalmazza az idevonatkozó előírásokat és szabályokat. A nem megfelelő minőségú fogpótlás előbb- utóbb káros hatással lesz a szájüregi képletekre [12, 19], amit nyilvánvalóan el kell kerülni. Ennek érdekében a fogorvosnak pontos utasításokkal kell ellátni a fogtechnikai labor munkatársait bármilyen fogpótlást, többek között részleges kivehető fémlemezes fogsorokat, rendel meg.

Az Európai Uniós direktívák szerint is pontos jogi és etikai iránymutatások vonatkoznak az egyedileg előállított orvosi „termékekre” [4], amiket minden gyakorló fogorvosnak követni kell(ene). A Brit Fogpótlástani Társaság részletesen leírta a részleges fogsorok tervezésére és készítésére vonatkozó szakmai irányelveket, amiben egyértelmúen megállapították, hogy a részleges fogsorok tervezése a fogorvos felelőssége és kötelessége [18], „The design of a partial denture is the duty and responsibility of the clinician".

A fogtechnikusok körében végzett felmérésünk szerint a fogorvosok nem tervezik meg mindig az öntött kapocs elhorgonyzású részleges kivehető fémlemezes múfogsorokat (továbbiakban: részleges fémlemezes múfogsorok) úgy, ahogy az elvárható lenne, ezért a kutatás második részében azt szerettük volna kideríteni, hogy a fogorvosok saját bevallásuk szerint hogyan járnak el, amikor részleges fémlemezes fogsort rendelnek meg a fogtechnikai laborból. Célunk volt felmérni, hogy a fogorvosok az öntött kapocs elhorgonyzású fémlemezes fogsorok készítéséhez küldenek-e, ha igen milyen részletes útmutatót a fogtechnikusoknak. További cél volt felmérni a fogorvosok véleményét, mire lenne szükség a rendelőben a tervezéshez, valamint milyen anyagokat használnak a lenyomatvételhez. 


\section{Anyag és módszer}

Az összeállított kérdőívet a 2020. januárban Szegeden az SZTE FOK által szervezett kötelező továbbképzés keretében töltötték ki a résztvevők önkéntesen és névtelenül, miután tájékoztatást kaptak a felmérés témájáról és céljáról. A kérdések egy része a laborba küldött utasítások tartalmára és minőségére vonatkozott, ezek: Készít-e pontos tervet, rajzot, leírást a fogtechnikusnak, kiválasztja-e a kapocstartó fogakat és kapocstípusokat, valamint a nagy összekötők formáját, berajzolja-e az egyéni kanál határait, figyelembe veszi-e a parodontálhigiénés szempontokat, milyen módon küldi az információkat a laborba. A kérdések másik témája a felelősségvállalás volt, vagyis a kollégák adott esetben magukat vagy a technikust okolják-e valamilyen hiba esetén. A további kérdések a rendelőben a tervezéshez szükséges eszközökre és anyagokra, valamint az alkalmazott lenyomatanyagokra vonatkoztak.

\section{Eredmények}

A kérdőívet 88 fogorvos töltötte ki, átlagosan 22 éve készítenek részleges fémlemezes müfogsorokat, kétharmaduk (67 fö, 76,1\%) megyeszékhelyen vagy nagyobb városban dolgozik. A fogorvosok $54,5 \%$-a válaszolt igennel arra a kérdésre, hogy készít-e pontos tervet, rajzot, leírást a fogtechnikusnak a fémlemezhez. (1. táblázat)
A kapocstartó fogakat 77 -en (88,5\%) jelölik meg, a kapcsok típusát $65,9 \%$ választja ki, a nagy összekötőkre nézve pedig $55,8 \%$-uk ad utasítást a labornak. A kollégák nagy többsége figyelembe veszi a parodontálhigiénés szempontokat ( 72 fő, $81,8 \%$ ), és meglehetősen sokan (37 fő, 42,5\%) vélték úgy, hogy egyértelmü, pontos utasítást küldenek a laborba. Kicsit nagyobb azok aránya (44 fő, 50,5\%), akik adnak iránymutatást, de több részletet a fogtechnikusra bíznak, és csak $8 \%$ (7 fö) ad kevés útmutatást, és a legtöbb részletet a fogtechnikusra bízza. Az információátadás módja kisebb részben rajzban ( 7 fö, $8,1 \%$ ), nagyobb részben szövegesen (29 fö, $33,7 \%$ ) történik és a legtöbben ( 50 fő, $58,2 \%$, ketten nem válaszoltak) a rajzos és szöveges utasítást tartják a legmegfelelőbbnek, még akkor is, ha a válaszadók nem mindig küldenek utasítást.

A felelősséget érintő kérdéskörben a következő válaszokat kaptuk (2. táblázat): Ha a fogtechnikus tervez, és esztétikai probléma lenne, a fogorvosok nagyrészt $(68,9 \%)$ magukra vállalják a felelősséget, vagy közösen oldanák meg a problémát a technikussal $(17,3 \%)$. Ha viszont a fogorvosi tervezés után nem elégedett a beteg az esztétikai megjelenéssel, akkor még nagyobb részben vállalják magukra az újrakészítés felelősségét $(90,9 \%)$ és csak 2 kolléga hárítaná azt teljesen a technikusra. Csak egyetlen technikai problémára kérdeztünk rá, nevezetesen, ha a rágófelszíni támaszték emel, és ennek az az oka, hogy a labor nem kapott antagonista lenyomatot vagy mintát a fémlemez megrendelésekor, tehát

A tervezésre vonatkozó kérdések és a válaszok aránya

\begin{tabular}{|c|c|c|c|c|}
\hline \multirow{2}{*}{ Kérdések } & \multicolumn{2}{|c|}{ Igen } & \multicolumn{2}{|c|}{ Nem } \\
\hline & $n$ & $\%$ & $n$ & $\%$ \\
\hline Készít-e pontos tervet, rajzot, leírást a fogtechnikusnak a fémlemezhez? $(\mathrm{N}=88)$ & 48 & 54,5 & 40 & 45,5 \\
\hline Kiválasztja-e a kapocstartó fogakat? $(\mathrm{N}=87)$ & 77 & 88,5 & 10 & 11,5 \\
\hline Kiválasztja-e a kapcsok fajtáját is? $(\mathrm{N}=85)$ & 56 & 65,9 & 29 & 34,1 \\
\hline Megtervezi-e a nagy összekötők formáját? $(\mathrm{N}=86)$ & 48 & 55,8 & 38 & 44,2 \\
\hline Figyelembe veszi-e a parodontálhigiénés szempontokat? & 72 & 81,8 & 16 & 18,2 \\
\hline Egyetért-e abban, hogy a tervezéshez beartikulált tájékoztató mintára van szükség? $(\mathrm{N}=84)$ & 62 & 76,0 & 22 & 24,0 \\
\hline Ha egyéni kanalat rendel a lenyomathoz, berajzolja-e a határokat? $(\mathrm{N}=85)$ & 56 & 65,9 & 29 & 34,1 \\
\hline Küld-e általában információt a beteg életkorára vonatkozóan? $(\mathrm{N}=88)$ & 79 & 89,8 & 9 & 10,2 \\
\hline
\end{tabular}

A felelősség témájában kapott válaszok

\begin{tabular}{|c|c|c|c|c|c|c|}
\hline \multirow{2}{*}{ Kérdések } & \multicolumn{2}{|c|}{ Fogorvost } & \multicolumn{2}{|c|}{ Fogtechnikust } & \multicolumn{2}{|c|}{ Mindkettőt } \\
\hline & $n$ & $\%$ & $n$ & $\%$ & $n$ & $\%$ \\
\hline $\begin{array}{l}\text { Ha a fogtechnikus tervez és a beteg esztétikai okok miatt nem fogadja el } \\
\text { a kész munkát, kit terhel a felelősség az újra készítésért? }(\mathrm{N}=87)\end{array}$ & 60 & 68,9 & 12 & 13,8 & 15 & 17,3 \\
\hline $\begin{array}{l}\text { Ha a fogorvos tervez, és a beteg esztétikai okok miatt nem fogadja el } \\
\text { a kész munkát, kit terhel a felelősség az újrakészítésért? }(\mathrm{N}=88)\end{array}$ & 80 & 90,9 & 2 & 2,3 & 6 & 6,8 \\
\hline $\begin{array}{l}\text { Ha a fogtechnikus tervez és a rágófelszíni támaszték miatt nem tud a beteg } \\
\text { teljesen összeharapni, akkor kit terhel a felelősség? PI. nem kapott a labor } \\
\text { antagonista mintát vagy lenyomatot, harapás regisztrátummal }(\mathrm{N}=87)\end{array}$ & 67 & 77,0 & 13 & 14,9 & 7 & 8,1 \\
\hline
\end{tabular}


Fogorvosok véleménye a fogtechnikusok részvételéröl a tervezésben

\begin{tabular}{|c|c|c|c|c|}
\hline \multirow{2}{*}{ Kérdések } & \multicolumn{2}{|c|}{ Igen } & \multicolumn{2}{|c|}{ Nem } \\
\hline & $n$ & $\%$ & $n$ & $\%$ \\
\hline $\begin{array}{l}\text { Szükségesnek tartja-e, hogy a részleges kivehető fémlemezes fogpótlások tervezésében } \\
\text { a fogtechnikus is részt vegyen? }(\mathrm{N}=88)\end{array}$ & 79 & 89,8 & 9 & 10,2 \\
\hline $\begin{array}{l}\text { Szükségesnek tart-e közös megbeszélést a fogorvos és fogtechnikus között } \\
\text { a fémlemezes fogsor készítése előtt? }(N=86)\end{array}$ & 79 & 91,9 & 7 & 8,1 \\
\hline
\end{tabular}

nem tudta a mintákat artikulátorba gipszelni és úgy ellenőrizni az okklúziós viszonyokat, akkor a legtöbb fogorvos (67 kolléga, 77,0\%) magára vállalta a felelősséget.

A rendelőnek milyen eszközökre van szüksége, hogy a fogorvos tervezni tudjon fémlemezes kivehető fogsort kapoccsal - kérdésre nagyon kevés választ kaptunk, csak 42 fő válaszolt. A válaszokban az artikulátort (14 fő), paralellométert (16 fő) és a gipszmintákat (15 fő) jelölték meg a kollégák. A tervezést (3. táblázat) közös munkának tartja a résztvevők legnagyobb (89,8\%) része, és fontosnak tartják a közös megbeszélést a fémlemezes fogsorok készítése előtt (91,9\%). A fogorvosok kis része (15,5\%, 13 fő) véli úgy, hogy minden esetben megvalósítható a tervezés a rendelőben, 28,6\% (24 fő) szerint ez nem működik, és 55,9\% (47 fő) gondolja úgy, hogy többnyire megoldható lenne (négyen nem válaszoltak).

A fémlemezes fogsorok megrendeléséhez nagyrészt szilikon lenyomatanyagot használnak manapság a fogorvosok $(96,2 \%)$, csak néhányan jelölték meg az alginátot (3 fó), tízen azonban nem válaszoltak erre a kérdésre.

\section{Megbeszélés}

A felmérésben részt vevőknek alig több mint a fele (54,5\%) állította csak, hogy pontos tervet mellékel a lenyomathoz, amikor öntött kapocs elhorgonyzású fémlemezes fogsort rendel meg a technikustól. Ez messze elmarad az európai uniós direktívától vagy egyéb szakmai előírásoktól. Sajnos hasonló arányokat lehet olvasni más felmérésekben is, tehát ebből a szempontból nem maradunk el más országoktól. Egy brazil vizsgálat szerint [6], amit fogtechnikai laboratóriumokban kiviteleztek, a fogorvosok 51\%-a bármilyen, a tervezésre vonatkozó utasítás nélkül küldte a mintákat. Akik információt küldtek (49\%), ezt részben a mintára berajzolva (35\%), írásban (2\%) vagy csak a rágófelszíni támasztékok berajzolásával (12\%) tették meg. Ez meglehetősen eltér saját felmérésünktől, ahol a legtöbben rajz és szöveg együttes alkalmazásával küldtek információt. Hasonló volt a helyzet az Egyesült Királyságban és Î́rországban egy 2005-ben megjelent közlemény szerint [10]. Ott az orvosok 50\%-a nagyon hiányos vagy semmilyen utasítást nem küldött a fogsorok megrendelésekor. Rosszabb adatokat kö- zöltek egy másik kutatásban [8], mely szerint a fogorvosok $89,5 \%$ ritkán vagy soha nem küld terveket a fogsorok készítéséhez az Egyesült Arab Emirségekben.

A fogorvos és a fogtechnikus közötti pontos, egyértelmű kommunikáció elengedhetetlen feltétele a jó minőségú munkának és ezzel a megfelelő betegellátásnak. A beteg számára minden szempontból megfelelő fogsor készítéséhez szükséges a fogorvos elméleti és gyakorlati tudása, tapasztalatai, a beteg alapos vizsgálata és a körültekintő tervezés, valamint a száj előkészítése, a klinikai lépések gondos kivitelezése. Ezt egészíti ki a fogtechnikus tudásán alapuló kivitelezés [3]. Szükséges tehát a megfelelő színvonalú információátadás és információáramlás a rendelő és a labor között. Saját vizsgálatunk és az irodalmi adatok alapján azonban ez nem mindig valósul meg. Ami az utasítások minőségét illeti, Kínában [17] 637 kérdőív feldolgozása alapján azt pontosnak találták 24\%-ban, közepesnek 45\%ban, gyengének 17\%-ban, és 14\%-ban nem volt tájékoztatás. Pontos információnak tekintették, ha a terv egyértelmú és világos volt, közepesnek, ha iránymutatást kapott a labor, de több részlet a technikusra volt bízva, és gyengének tekintették, ha az utasítás pontatlan volt, és a tervezés nagyrészt a technikusra volt bízva. Jelen felmérésben nagyobb volt azok aránya (42,5\%), akik saját minősítésük szerint egyértelmű, világos, pontos utasítást adnak, hasonló azok aránya (50,5\%), akik adnak iránymutatást, de több részletet a fogtechnikusra bíznak, és csak $8 \%$ ad kevés útmutatást. Mindez némi fenntartással kezelendő, mivel arra a kérdésre, hogy pontos tervet készít-e, csak 54,5\% válaszolt igennel. A két válasz között így azonban némi ellentmondás fedezhető fel. Nem szabadna elfelejteni azt sem, hogy a labornak küldött írásos utasítás vitás esetben a problémát tisztázó dokumentumként is szolgál, kiderül, ki a felelős az esetleges hibás tervezésért [17].

A felelősség kérdése is érdekes eredményre vezetett, miszerint a fogorvosok kis része akkor is a fogtechnikusra hárítja a felelősséget, ha ő végzi a tervezést $(6,8 \%)$, vagy éppen nem küld megfelelő lenyomatokat (14,9\%) a laborba. A felmérésben magyarázatot nem kértünk, de érdekes lenne kideríteni, mi lehet ennek az oka.

Jól mutatja az utóbbi évtizedek minőségjavulását, hogy alig használnak a fogorvosok alginátot a lenyomatvételhez fémlemezes fogsor késztéséhez, ami még a múlt század hetvenes éveiben elfogadott volt; szilikonokkal egyértelmúen pontosabb lenyomatok készíthetők [13]. 
Célszerū lenne feltárni az okokat, amiért a fogorvosok nálunk is nagy részben a fogtechnikusokra hárítják a fémlemezek tervezését. A fogtechnikus a legjobb szándéka mellett sem rendelkezik a betegre vonatkozó és a fogsor készítéséhez szükséges minden információval, amikor rendszerint csak lenyomatot kap a fogsor megrendelésekor.

Felmerül a kérdés, mi lehet az oka annak, hogy a fogtechnikusok és a fogorvosok válaszai szerint sem kerül megfelelő tájékoztatás a laborba a fogsorok tervezéséhez. Lehetséges indok az időhiány, de ok lehet a fogorvosok nem elég jó felkészültsége is. A képzésbeli eltérésekkel több közlemény is foglalkozott $[2,7]$, amelyek alapján valószínüsíthető, hogy a fogorvosok képzésében nagyobb szerepet kellene kapjon a részleges foghiányos betegek kezelésének elméleti és gyakorlati háttere. Feltehetően hasznos lenne a képzésbe a fogtechnikusokat is bevonni, föleg a fogtechnikai lépések gyakorlati bemutatásához. Fontos lenne az egyetemi oktatás bővítése, továbbképző tanfolyamok szervezése és látogatása a részleges foghiányos betegek ellátása témakörben, és a rendelőkben egy egyszerű paralellométer beszerzése és használatának elsajátítása. Ma már lehetőség nyílik a digitális tervezés oktatására is [11], ami a fiatal generáció számára kedvező tanítási forma lehet. Arra is van példa, hogy fogorvostan-hallgatóknak és fogtechnikus-tanulóknak közös kurzust tartanak a részleges kivehető fogpótlások témájában [15]. A megfelelő képzés feltétele a fogorvosok magabiztosságának és megbízható ismereteinek, aminek köszönhetően a trend feltehetően javulna, vagyis egyre több fogorvos tervezné meg a részleges fémlemezes múfogsorokat.

Az Európai Parlament és a Tanács [16] 2017/745 rendelete pontosan megfogalmazza: „the medical care provided to the subjects is the responsibility of an appropriately qualified medical doctor or, where appropriate, a qualified dental practitioner". Eszerint minden fogorvosnak szem előtt kell tartania, hogy az Európai Uniós jog szerint a „betegeknek nyújtott orvosi ellátás a megfelelő képesítéssel rendelkező orvos vagy adott esetben a képzett fogorvos felelőssége".

\section{Következtetés}

A felmérés alapján, amelyben nem túl sok kolléga vett részt, a fogorvosok jelentős része nem tervezi meg pontosan a készítendő öntött kapoccsal elhorgonyzott részleges kivehető fémlemezes fogsorokat, hanem a fogtechnikusokra bízza. Ez a gyakorlat azonban ellentétes a jogi, etikai és szakmai szabályokban, útmutatókban megfogalmazott követelményekkel. A szakma irányítóinak és a fogorvostan-hallgatók képzéséért felelős döntéshozóknak meg kellene találni azokat a módszereket, amelyekkel a fogorvosok segítségére lehetnek a probléma megoldásában, $s$ ez egyértelmúen a betegellátás minőségének javulását eredményezné.

\section{Irodalom}

1. A Magyar Orvosi Kamara Etikai Kódexe https://mok.hu/public/media/source/etikaiKodex/ EtikaiKodex_2018_11_24.pdf (2020.06.21.)

2. CLARK RK, RADFORD DR, JUSZCZYK AS: Current trends in removable partial denture teaching in British dental schools. Br Dent J 2011; 211 (11): 531-535. https://doi.org/10.1038/sj.bdj.2011.1003

3. Davenport JC, Basker RM, Heath JR, Ralph JP, Glantz Po, Hammond P: Communication between the dentist and the dental technician. Br Dent J 2000; 189 (9): 471-474. https://doi.org/10.1038/sj.bdj.4800803

4. EC Medical Devices: Directive No 10. Guidelines to medical devices directives 93/42/EEC for manufacturers of custom-made dental devices.

Dublin, Department of Health and Children, 1997

5. 1997. évi CLIV. törvény az egészségügyröl https://net.jogtar.hu/jogszabaly?docid=99700154.tv (2020.06.21.)

6. Farias-Neto A, da Silva RS, da Cunha Diniz A, Batista AU, CARREIRO AD: Ethics in the provision of removable partial dentures. Braz J Oral Sci 2012; 11: 19-24.

7. Figueiral MH, Fonseca P, Campos JC, Correia AR, Fernandes MS Branco FJ: Removable partial denture education in Portugal following the Bologna Process. Eur J Prosthodont Restor Dent 2013; 21 (3): 127-134.

8. Haj-Ali R, Al QuRan F, Adel O: Dental laboratory communication regarding removable dental prosthesis design in the UAE. J Prosthodont 2012; 21 (5): 425-428. https://doi.org/10.1111/j.1532-849X.2011.00842.x

9. 2013. évi V. törvény a Polgári Törvénykönyvröl https://net.jogtar.hu/jogszabaly?docid=a1300005.tv

10. LYNCH CD, ALLEN PF: Quality of written prescriptions and master impressions for fixed and removable prosthodontics: a comparative study. Br Dent J 2005 Jan 8; 198 (1): 17-20. https://doi.org/10.1038/sj.bdj.4811947

11. Mahrous A, Schneider GB, Holloway JA, Dawson DV: Enhancing Student Learning in Removable Partial Denture Design by Using Virtual Three-Dimensional Models Versus Traditional Two-Dimensional Drawings: A Comparative Study. J Prosthodont 2019; 28 (8): 927-933. https://doi.org/10.1111/jopr.13099

12. Petridis H, Hempton TJ: Periodontal considerations in removable partial denture treatment: a review of the literature. Int J Prosthodont 2001; 14: 164-172.

13. Peutzfeldt A, Asmussen E: Accuracy of alginate and elastomeric impression materials. Scand J Dent Res 1989; 97 (4): 375-379. https://doi.org/10.1111/j.1600-0722.1989.tb01626.x

14. RADNAI M: A fogmúvek készítésének jogi vonatkozásai. In Radnal M: Részleges kivehetó fogpótlások. Medicina, Budapest 2012; 209-211.

15. Reeson MG, Walker-Gleaves C, Ellis I: Attitudes towards shared learning of trainee dental technicians and undergraduate dental students. $J$ Dent Educ 2015; 79 (1): 95-100. https://doi.org/10.1002/j.0022-0337.2015.79.1.tb05862.x

16. Regulation (EU) $2017 / 745$ of the European Parliament and of the Council of 5 April 2017 on medical devices, amending Directive 2001/83/EC, Regulation (EC) No 178/2002 and Regulation (EC) No 1223/2009 and repealing Council Directives 90/385/EEC and 93/42/EEC https://eur-lex.europa.eu/legal-content/EN/TXT/?uri=CELEX\% 3A32017R0745 (2020.06.30.)

17. SuI L, WuX, Wu S, GAO P, LI R: The quality of written instructions for dental prostheses in China. J Prosthodont 2014; 23 (8): 602-609. https://doi.org/10.1111/jopr.12163

18. Winstanley RM, Barsby MJ, Ogden AR, Welfare RD: Guides to Standards in Prosthetic Dentistry - Complete and Partial Dentures. Produced by a working party from BSSPD 
and approved by the Council of BSSPD. Updated 2005 https://www.bsspd.org/About/BSSPD+guidelines.aspx

19. Zlatarić DK, Celebić A, Valentić-Peruzović M: The effect of removable partial dentures on periodontal health of abutment and non-abutment teeth. $J$ Periodontol 2002; 73: 137-144. https://doi.org/10.1902/jop.2002.73.2.137

\section{Original article}

Radnal M, Baráth Z, Albert B, Tarjányı T, Marada Gy

\section{Removable partial denture design in the general dental practice II.}

Professional, legal and ethical guidelines and rules guide the duties and responsibilities of dentists in relation to patient care, including the fabrication of removable partial dentures with cast clasp retained metal framework. The aim of our study was to assess the extent to which dentists follow these standards in the daily practice. Data were collected using a questionnaire and the responses of 88 dentists were analyzed. Based on our results, about half (54.5\%) of the participating dentists send a precise denture design to the laboratory to be used in the preparation of a metal framework, $88.5 \%$ specify the abutment teeth, $65.9 \%$ choose the type of the clasps and $55.8 \%$ gives instructions for the major connectors. A small percentage of dentist provide information to the lab in drawing $(8.1 \%)$, it is more common to send textual instructions $(33.7 \%)$ and most dentists $(58.2 \%)$ send drawings and written instructions together. Most of the dentists consider periodontal hygiene aspects $(81.8 \%)$ and almost half of them $(42.5 \%)$ consider that they send clear, precise instructions to the lab. A slightly higher proportion (50.5\%) gives guidance but leaves more details to be decided by the dental technician and only $8 \%$ provide very little guidance and leaves most of the details to the dental technician. Dentists mostly (96.2\%) use silicone impression material for the definitive impression to make the metal framework, only a few of them mentioned alginate. Dentists are largely willing to take responsibility in the event of an error and believe that planning together with the dental technician is important. To ensure that based on the patient-related information dentists always, or at least more often design the removable partial dentures with metal framework, the theoretical and practical knowledge needs to be broadened during university education and in continuing education courses.

Keywords: dentist, dental technician, denture design, clasp retained removable partial denture, responsibility 